Anuario Latinoamericano Ciencias Políticas y Relaciones Internacionales vol. 6, 2018

pp. 121-143

\section{The role of the state of Hidalgo in the public policies for the Hidalgo inhabitants abroad}

\section{El papel del Estado de Hidalgo en las políticas públicas para los Hidalguenses en el exterior}

\author{
Edgar Manuel Castillo Flores ${ }^{\star}$ \\ POLITICAL SCIENCES AT THE UNIVERSITY OF THE STATE OF HIDALGO \\ PACHUCA, MEXICO \\ $\triangle$ edgar_castillo@uaeh.edu.mx \\ https://orcid.org/0000-0003-0717-9034 \\ Berenice Alfaro Ponce** \\ POLITICAL SCIENCES AT THE UNIVERSITY OF THE STATE OF HIDALGO \\ PACHUCA, MEXICO \\ $\triangle$ berenice_alfaro@gmail.com \\ https://orcid.org/0000-0002-7046-1019
}

\begin{abstract}
In 1990, the migration of the inhabitants of the Hidalgo state to the United States was intensified, becoming an emergent social phenomenon. In response to this, in 1999, the authorities of the state of Hidalgo made some intervention efforts. The aim of this document is to describe the antecedents of the public policies developed by the Hidalgo government in the care of its migrants in the United States, through a methodology of historical and qualitative analysis that investigate three governmental periods of management and various initiatives developed by the state.
\end{abstract}

* B.A. in Political Sciences and Public Administration by the Autonomous University of the State of Hidalgo, Master in Local Development by the Polytechnic University of Madrid and Ph.D. by the Complutense University of Madrid, with a double degree in Government, Public Policies, Sociology and Anthropology. Currently he is a full-time researcher seconded to the academic area of Political Science and Public Administration with a required PRODEP profile and a coordinator of the B.A in Political Sciences and Public Administration. His areas of research are public policies, local development, migration and development.

$* *$ B.A. in International Relationships by the Autonomous University of Guadalajara. She obtained her Master's Degree in Human Rights and Democracy by the Latin American Faculty of Social Sciences in Mexico, where she researched topics related to vulnerable groups, specifically indigenous women and federal programs in Mexico. She obtained her Ph.D. in Social Sciences by the Autonomous University of the State of Hidalgo, where she continued to develop the topic of public policies, vulnerable groups and intercultural competence. Currently she is a full-time researcher seconded to the academic area of Political Science and Public Administration with a required PRODEP profile. 


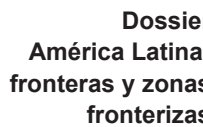

KEYWORDS: public policy, migration, Mexico, Hidalgo.

\section{RESUMEN}

A partir de 1990 la migración hacia los Estados Unidos de los hidalguenses se intensificó, posicionándose entonces como un fenómeno social emergente. En respuesta al mismo, las autoridades del estado de Hidalgo, en el año 1999, hicieron esfuerzos de intervención. El objetivo de este documento es describir los antecedentes de las políticas públicas desarrolladas por el gobierno de Hidalgo en atención a sus migrantes en Estados Unidos, esto a través de una metodología de análisis histórico y cualitativo para investigar tres períodos gubernamentales de gestión y las diversas iniciativas desarrolladas por el gobierno estatal.

PALABRAS CLAVE: política pública, migración, México, Hidalgo.

\section{Introduction}

During the last years, the migration of Mexicans to the United States has been a social phenomenon occurring in almost all the Mexican territory. Although the state of Hidalgo had not had a wide migratory tradition, since 1990 it began experiencing an increase in its migratory intensity index, until it reached one of the highest rates in the country (CONAPO 2002). ${ }^{1}$

The present text focuses on the study of migration and its social impact. There are many studies that have addressed this subject, and many are the methodologies and approaches that could be applied from social sciences, anthropology, historical social movements, intercultural studies and some others. For this particular case, we decided to use the transnational approach for migration studies (Portes et al. 1999). In addition to this, we used a qualitative methodology to interpret the analyzed information, in order to understand behaviors around the causality or not of migration. Moreover, we have chosen to customize the methodology of the case studies especially to concretize real effects of the analyzed phenomena.

Above all, the text is placed in an explanatory paradigm that tries to establish conclusions in terms of causality. This type of research turns out to be the most interesting from the theoretical point of view, since the data collected indicate whether or not there is correlation and, in some cases, also allow inferring whether the alleged cause is earlier than the effect considered (Anduiza et al. 1999: 29).

Meanwhile, the case study was established as a research strategy, which is a model widely used in the field of social sciences, particularly in sociology,

1 The migratory intensity index (CONAPO 2012) considers the demographic and socioeconomic dimensions of the international migration and is a type of measure that differentiates the states and municipalities of the country, according to the intensity of the different types of migration to the neighboring northern country and the reception of migrant remittances (CONAPO 2012). 
anthropology and political science. We chose this strategy, taking advantage of the facility to establish indicators that will allow us to investigate a single unit of analysis (the state migration policy) of which many properties are considered at a given time (Anduiza et al. 1999). ${ }^{2}$

In view of the migration situation, the Hidalgo authorities are aware of the emerging issues and have tried to actively intervene in this process, but their answer has not been commensurate with the phenomenon's needs, since their involvement just started the last decade. Before 1999, the state policy demonstrated an indifference towards the people from Hidalgo living abroad. Such position followed the traditional line of "non-politics policy" on migratory issues (García, Grieco, Verea 1988).

The government's change of vision regarding the migratory phenomenon took place during the administration of the governor Manuel Angel Nuñez Soto (1999-2005). Since then, migrants from Hidalgo were included in the political state agenda, therefore, an office was created to handle the requests of the migrants from Hidalgo living in the United States: CAHIDEE - Care Coordination to People from Hidalgo in the State and Abroad (Coordinación de Atención al Hidalguense en el Estado y el Extranjero). In 2015, its name changed to General Directorate of Attention to Migrants - DGAM (Dirección General de Atención al Migrante).

DGAM has designed a care migratory model that seeks to permanently get involved with migrant communities from Hidalgo living in the United States in addition to meet the family needs of migrants in their place of origin. Its operation is divided in three aspects: first, it has managed programs coming from the federal administration in a decentralized way; secondly, it has taken in the initiatives of other states with greater migratory experience; and finally, it has designed its own programs to serve the migrants from Hidalgo.

\section{The transnationalism and the linking policies of the countries of origin with their own migrants}

During the last years, a great quantity of social studies has proven the importance of the links between international migrants and their societies of origin and destiny. In a big amount, this literature has emphasized the way in which the arrival of new technologies and the appearance of the information society has speeded up the connection between different places of the world and originating new social phenomena which have led these social links to

2 The reasons that led us to the use of the case study were based on two advantages. First, the cost in terms of access to data, information and the simplicity of the research design. Secondly, concentrating on a single case allows intensive research to be followed. That is to say, a large number of properties of the case are considered and its importance is evaluated in the complex network of relationships that constitute every sociopolitical phenomenon (Bartolini 1999).
The role of the state of Hidalgo in the public policies for the Hidalgo inhabitants abroad

Edgar Manuel Castillo Flores Berenice Alfaro Ponce 
Dossier América Latina: fronteras y zonas fronterizas unpredictable and unimaginable scenarios (Portes et al. 2003). The studies on migrants' relations with their countries of origin and destiny are strongly influenced by the presence of the transnational perspective in the study of migrations. The first researches surged in 1999 and, over time, took much more relevance. In this moment, Glick Schiller and a group of researchers (Schiller et al. 1992) found that groups of migrants in the United States developed a series of everyday behaviors that the conventional migratory theories couldn't precisely explain; they discovered that, far from assimilating to the United States society, migrants kept numerous social practices that allowed them to have a strong bond with their communities of origin. The concept of transnationalism means "all activities and jobs that require habitual contacts and sustained through national borders for its execution" (Portes et al. 2003: 18). The definition of Portes contemplates, for instance, such migrants that endeavor in monthly trips to their places of origin in order to deliver some sort of correspondence to their relatives, friends or acquaintances within their community. However, it does not include the occasional gifts in money or objects that the migrants send to their families, for it is not an occupation as such; it also doesn't include the cases in which a migrant buys a house in his/her country of origin.

The occasional activities described previously contribute to strengthen the field of study of transnationalism, however, they don't end up being of sufficient novelty to justify a new field of research (Itzihsohn et al. 1999). What gives support to this new area of studies is the great intensity of changes, the new ways of transaction and the multiple activities that are constantly crossing national borders between the origin and target countries.

In this sense, Portes et al. (2003) establish as a unit of analysis an individual migrant and their social networks, while excluding other factors, such as big companies, political parties or local governments. The reason to discard such social factors is not justified in conceptual terms, but as a methodological strategy. Since, according to Portes, the migrant transnationalism is an expression that surged from the basis, in other words, transnational activities that were not initiated by local or national governments or big corporations. On the contrary, all these activities of transnational matters correspond to a reaction of migrants against governmental politics and the dependent capitalist conditions that underdeveloped countries suffer. In this way, it is considered that the transnational activities of migrants surge as an answer to avoid the conditions of poverty and marginalization that affected them in their original and destiny contexts (Smith 2006 cited by Portes et al. 2003). The intervention of governments and companies surges later in response to the recognition of the importance and impact that migrant communities have in the social network of their original country, which leads the governments and private companies to interfere actively in this process, mainly looking to direct and redirect these initiatives (Portes et al. 2003, Portes, De Wind 2006).

Firstly, the economic transnationalism that includes the activities of migrant businessmen in the places of settlement, which mobilize their acquaintances 
through the borders seeking for clients, providers, capital and market; also there are the activities of small and medium size business created by migrants who returned to their country of origin; the multinational investments or the banking activities of financial groups in the country of origin which open business offices in the places of the biggest settlements of migrants. Secondly, there is the political dimension of transnationalism that is developed mainly by political parties, government officials and the leaders of organizations of migrants whose natural goal is to obtain power and political influence in the country of origin as well as in the country of destiny. Their initiatives include the assignment of political rights such as a double nationality, voting in foreign country or the proselytism of any candidate in the country of origin. The last category comprises the sociocultural practices oriented to reinforce the national identity of the migrants abroad, for example: trips of folkloric groups or musicians to perform for an immigrant audience; the organization of events, competitions or sports leagues; the election of beauty queens to represent the migrant community or the realization of artistic events within the country of destiny.

The second dimension differentiates the transnational activities started and directed by powerful institutional actors such as multinational corporations and/or the nation states from the activities carried out by actors with minor institutional level such as migrants and their families in the countries of origin. This category of activities is commonly known as up and down transnationalism (Guarnizo 1997).

The advantage of using Portes et al. (1999) typology lies in its usefulness to analyze empirically the transnational migratory phenomenon depending on the actor (social, political or economic), which can be either institutionally powerful government or a modest migrant (Blanco 2007). To summarize, the practices and activities of economic, political or sociocultural aspect in migrant communities acquire a strictly transnational sense when done in a regular and systematical way, through the national borders, generating a sort of interactive channel within the places of origin and target, denominated as a social transnational space. From this moment onwards, the transnational approach started to be more valued for its capacity to renew and enlarge the perspective of the international migratory studies, to such a degree that it has consolidated itself as one of the most commonly used analytical frames by specialized social researchers in international migrations. At the same time criticism appeared regarding its theoretical foundation and its methodology. However, it is of utmost importance that this research highlighted elements, concepts and social actors that until then had never been mentioned within the conventional migratory theories such as the inclusion of the participatory analysis of the different levels of the government within the migratory phenomenon.

In this sense, not long ago the entailment of migrants with their communities of origin has turned into a growing concern for national governments, since
The role of the state of Hidalgo in the public policies for the Hidalgo inhabitants abroad

Edgar Manuel Castillo Flores Berenice Alfaro Ponce 
Dossier América Latina: fronteras y zonas fronterizas it is obvious that migrants keep connections with their places of origin and target destination. Thus, in the face of complexity regarding the migratory process, the government authorities have not been distant, on the contrary they have implemented a series of programs, laws, actions and very specific politics that have been focused to boost and strengthen a closer relationship with their migrant communities abroad. However, these actions have been more frequent in the countries of origin and have been occurring with less frequency in the target countries.

\section{The state government and its migrant community, a brief recap}

Although the migratory phenomenon between Mexico and the United States dates back more than a hundred years, the official link between the Mexican government and its migrants in the United States was a pending issue on its political agenda. The formal approach between both parties occurred in the 1990s with the implementation of the Program for Mexican Communities Abroad -PCME (Goldring 1999). As a part of this initiative, the federal government determined, as one of its main lines of action, that local governments should be involved in migratory issues and initiate relationships with its migrants settled in the United States.

The response of the state governments to the demands of the PCME was diverse: the states with greater migratory tradition and intensity like Zacatecas, Michoacán or Guanajuato, widely collaborated to the point of creating offices and institutions that were responsible for migratory services. They even implemented innovative programs of productive investment using remittances (Moctezuma 2003, Valenzuela 1999, Smith and Bakker 2008). On the other hand, states with the lowest migratory intensity did not participate in the program and they followed the line of the known "politics of the non-politics" in migratory issues (García, Grieco, Verea 1988).

The local government position in Hidalgo regarding these issues has varied considerably due to the natural passing of time and transformations it has faced in several aspects. Prior to 1990, it was difficult to find evidence of any migration care policy in the state. However, between 1990 and 1998, when the federal government started its approach, state authorities simply managed the policies that came from the federal level in a decentralized way. However, this activity was carried out without the necessary administrative process or without taking into account the needs of migrants. This indifferent behavior is not surprising, since all governors of the state to date have been militants of the Institutional Revolutionary Party (PRI), reason why, in a way, the governors adopted and kept the same traditional position that the party had presented with regard to the migratory phenomenon until 1990.

The local authorities' lack of interest towards migration was so evident that, although national initiatives and programs already existed (Goldring 2002) and 
the state had a considerable migratory flow (Serrano 2006), their participation did not correspond to the demands of the phenomenon.

An example was the coverage of the Bienvenido Paisano program, which initially only operated only during vacation periods in Mexico. However, migrants from Hidalgo would come back at a different time period such as at the end of the agricultural season.

In this context, during the return to their places of origin, Hidalgo migrants were subject to various abuses and robberies by organized crime. Surprisingly, they also suffered from these circumstances from the Mexican police authorities in border customs as well as on their journey to their places of origin. Moreover, although Hidalgo migrants reported the facts to the proper authorities, the state government had serious limitations in dealing with the complaints or they simply ignored them.

Because of that, migrants from Hidalgo started to look for their own means of support and protection, and they received help from non-governmental organizations. Such was the case of the migrants from Valle del Mezquital, who - because of the lack of concern showed by the state government - turned to the unofficial protection offered by the Supreme Council of the Hñahñu.

Regarding these facts, one of their former leaders mentioned: “...we were attentive and saw that in order to fight back these situations of mistreatment that our partners suffered, it was necessary for us to participate in the solution. That is why we started to create our own defense through our organization...”. This testimony mentions the participation that the Council had in the migratory issues in the state. In fact, during the 1990s, the leadership shown by this group played a crucial role in the support and defense of migrant workers from Hidalgo in both the United States as well as in Hidalgo. In addition, according to Schmidt and Crummett (2004), several reports from their leaders point out that this organization was a fundamental piece for the establishment of the migration service office in Hidalgo.

In the context of the increasing migratory flow of Hidalgo's people to the United States since the late 1980s, the active participation of other states in the face of international migration experienced in their regions (e.g. Zacatecas or Michoacan), the economic impact of Hidalgo's migration in the form of monetary remittances and, above all, the fact that some activities of the government of the state of Hidalgo on migratory issues were replaced by initiatives of the migrants themselves, in October 1999, the then governor of Hidalgo, Manuel Angel Nuñez Soto (1999-2005) created the General Coordination of Support to the People from Hidalgo in the State and Abroad (CAHIDEE), an agency which directly addresses the phenomenon.

It is not surprising that CAHIDDE was established during the Nuñez Soto administration, since, before he became governor, he had served as a head of the Mexico Office in Canada and participated in negotiations of the North American Free Trade Agreement (NAFTA). Hence, he had experience in the role that migrants played during NAFTA's approval, given the great political,
The role of the state of Hidalgo in the public policies for the Hidalgo inhabitants abroad

Edgar Manuel Castillo Flores Berenice Alfaro Ponce 
Dossier

América Latina:

fronteras y zonas

fronterizas economic and social influence they had acquired in their regions of origin during the 1990s.

At the end of Nuñez Soto's administration in April 2005, CAHIDEE was consolidated in administrative terms, since it had a series of projects and initiatives for migratory attention. During the transition to the governorship of Miguel Angel Osorio Chong (2005-2011), migration issues were given continuity, keeping them within the government's agenda and expanding their presence in other fronts. Then, for the first time, migratory attention was included in the State Development Plan (PED) 2005-2011 (Government of the State of Hidalgo 2005b). However, the objectives set out were rather broad and to some extent ambiguous. In general, the plan established the need to implement a policy on population studies and the definition of development policies that would generate alternatives to curb migration and its effects on the state.

The follow up of migratory attention was a recurrent issue in the administration of Miguel Osorio, at least in a normative sense. For starters, in December 2006, when the Social Development Law of the State of Hidalgo was enacted, migrants were considered as a part of vulnerable groups and needed priority attention.

Subsequently, the Law for the Protection of Migrants of the State of Hidalgo was promulgated, which began to regulate its legal protection within the state territory. Finally, in 2007, when presenting the State Development Plan Update 2007-2011 (Government of the State of Hidalgo 2007) it could be seen that the state authorities had learned from this, since it was reflected in their objectives that aimed to understand the migratory phenomenon as an element for planning the regional development and strengthening social programs in municipalities with high migratory intensity and to offer development alternatives and strategies to reinforce the migrants' belonging to their communities of origin. In other words, in addition to studying migration and creating alternatives to stop it, they would also seek to meet the demands of migrants both in Hidalgo as well as in the United States.

At the end of Miguel Osorio's term of office in March 2011, migratory attention enjoyed continuity in the political agenda of the following term. In the election to the governorship for the 2011-2016 period, there was a political conjuncture never seen before in the state. For the first time in its history, the electoral environment of Hidalgo crossed its boundaries and had important effects in the United States.

This was due to the fact that the main aspirants to the governorship, Francisco Olvera Ruiz, candidate of the PRI, and Xóchiltl Gálvez, opposing candidate of the PAN-PRD alliance, made proselytizing visits to Hidalgo migrants in the cities of Houston, Texas and Tampa Bay, Florida, respectively. In the end, the result of the election was favorable for the official candidate of the PRI, who, as acting governor, instructed that the migrants be included as one of the vulnerable groups within the State Development Plan 2011-2016 
(Government of the State of Hidalgo 2011). By the year 2015, CAHIDEE was to disappear and now it would acquire the category of General Directorate of Attention to Migrants (DGAM).

\section{The General Directorate of Attention to Migrants in Hidalgo}

From the creation of the CAHIDEE in 1999 and until its transformation into the General Directorate of Attention to Migrants in Hidalgo (DGAM) in 2015, the main functions of this public body have been to include the migratory issues in the political agenda of the state government and to implement support and linkage actions to meet the needs of the communities from Hidalgo settled in the United States.

However, at the beginning, this office had serious inconveniences and difficulties of internal administration, such as its location within the organizational chart of the public state administration. In the beginning, the CAHIDEE was a part of the Ministry of Finance, where it remained for a couple of months. Then, it became a part of the governor Nuñez Soto's office, where it served as an advisory body. Subsequently, it was included in the government secretariat where, in October 2004, it was consolidated as a decentralized administrative body in charge of the execution of migratory programs. Finally, since 2005 and until this date, it has been located in the structure of the Ministry of Social Development, due to the operation of the 3x1 Program for Migrants (Trejo 2010, SEDESO 2005, Vargas 2007). Therefore, it is under the Undersecretary of $\mathrm{Hu}-$ man and Social Development.

In addition to this, financing for the General Directorate of Attention to Migrants has been one of its main difficulties, because until October 2004, when it became a decentralized body from the public state administration, the unit began to receive its own resources in order to operate. However, the financial amount depends on other factors such as the political and economic context, the timely delivery of resources by the federal government and the allocation and availability of the budget expenditures established by the Ministry of Finance of the state of Hidalgo.

As an example, in 2005, during the governorship transition period, the CAHIDEE received one million pesos for its first months of operation (MayDecember). In 2006, it obtained about 11 million pesos, while the following year, as a result of the presidential change in Mexico, the budget was reduced to 2 million pesos. At the beginning of 2008, the federal government provided the necessary resources to the state of Hidalgo and the state allocated a 10 million pesos budget for migratory attention. However, the following year, due to the global economic and financial crisis, the budget was reduced again to approximately 3 million pesos.

Despite the aforementioned drawbacks, the DGAM is currently better defined. Its internal structure, according to the Organic Law of Public
The role of the state of Hidalgo in the public policies for the Hidalgo inhabitants abroad

Edgar Manuel Castillo Flores Berenice Alfaro Ponce 
Dossier América Latina: fronteras y zonas fronterizas
Administration for the State of Hidalgo, defines it as an agency that depends on the Undersecretariat of Social Programs, included in the Secretariat of Social Development of Hidalgo. Its organizational chart shows three directorates (Programs for the Attention to Migrants, Linkage and Houston House); three subdirectorates (Legal Procedures, Expert Translator and Administrative) and six support departments (Migration Assistance, Projects for Migrants, Communities Abroad, I am already from Hidalgo, Repatriation and Hearings). The Internal Regulations of the Ministry of Social Development point out that this organization has 32 specific functions that revolve around three action axes: the design of advisory programs, productive projects, investment, academic and protection of migrants from Hidalgo; the strengthening of migrant communities abroad and support and legal advice for people from Hidalgo living abroad.

Since the creation of the CAHIDEE in 1999, migratory attention has included the following actions: it has taken over the management of existing federal policies such as the Bienvenido Paisano program, adapting it to the state context; it continued to respond to the requests of migrants and their families through corrective protection programs such as legal assistance or the removal of mortuary remains; it encouraged the creation and consolidation of organizations for migrants from state of Hidalgo (CAHIDEE 2005). In its second year of operation, the institution became a founding and active member of the National Coordination of State Offices for Migrant Care (CONOFAM) through which it was able to exchange its experiences with offices from other states.

Among these initiatives, the Linkage Mechanisms program was established, in order to set up communication links by means of the retransmission of television and radio programs in the places of greater settlement of people from Hidalgo in the United States. In that same year, the Migrant Care program began to operate, whose objective was to strengthen the roots and sense of belonging of the migrants, by managing visits of artistic and cultural groups from Hidalgo in North America. The Let's Talk Migration initiative also started and it focused on reporting the risks and dangers faced by migrants when trying to cross the borders illegally.

In 2002, Hidalgo's policy sought to extend the rights of migrants by means of the dual nationality of their children born in the United States through the I am already from Hidalgo program. It also started to promote academic studies on international migration with the Permanent Observatory of International Migration. Likewise, programs that sought to integrate Hidalgo's migrants in the development were implemented and they gave way to the creation of their own initiative Peso x Peso, Dólar x Dólar, which had the objective of encouraging the participation of migrants in charitable works for their communities of origin. The programs 3x1 for Migrants and the pilot program Migrant Invest in Hidalgo were set in motion (thanks to the management of federal initiatives). Both programs were intended to give a new destination to 
the savings of migrants, taking advantage of their capacities for the formulation of social and productive projects.

In 2004, financial investment initiatives continued to be boosted with programs such as Small and Medium Investment, aimed at the creation of SMEs and the construction of housing in their community of origin. At that moment, the institution began to collaborate indirectly with the Ministry of Health (SSA) and with the Ministry of Public Education (SEP), in the Binational Programs of Migrant Education and Health, Go Healthy, Come Back Healthy, which seek to give attention to the needs in education and health of the Hidalgo migrants. However, the participation in those programs was reduced, at least until 2012.

Furthermore, academic studies were initiated regarding the main causes and repercussions of the migratory phenomenon in the state and programs for the use of remittances started to be promoted. But the most important thing was that the government of the state of Hidalgo sought to actively engage with the migrant community in the United States, to the extent that it began to address their demands and recognize their presence in the state, which led to the institutionalization of their relations through an office responsible for that subject.

\section{Continuity and the attempt of the integral migratory attention}

In the political transition to the governorship of Miguel Angel Osorio Chong (2005-2011) there was continuity in the government's attitude towards migration and new programs were even created. In fact, the inclusion of migrants in the State Development Plan 2005-2011 (Government of the State of Hidalgo 2005b) led to the establishment of the State Program of Migrant Care (SEDESO 2005) which had the purpose of providing counselling and support for people from Hidalgo in the United States as well as their families in Hidalgo. In this sense, the strategies of the program included five general competences that would be carried out by means of four lines of action (preventive, corrective, productive investment and social and community development actions). These lines, in turn, established the operational programs that would work during that government term.

A great part of the implemented programs continued as the case of Bienvenido Hidalguense; Support and Orientation for Migrants in the State; Let's Talk Migration; I am Already from Hidalgo; 3x1 for Migrants; Peso x Peso, Dólar x, Dólar, Migrant Invest in Mexico and all the corrective protection actions (SEDESO 2005). Also the Binational Programs of Education and Health, Go Healthy, Come Back Healthy continued to be supported.

In addition, as considered by the state government, the modified programs to improve or extend its operation were the Observatory of International
The role of the state of Hidalgo in the public policies for the Hidalgo inhabitants abroad

Edgar Manuel Castillo Flores Berenice Alfaro Ponce 
Dossier América Latina: fronteras y zonas fronterizas
Migration, which became the program of Investigation and Analysis of Hidalgo's Migration. Another case was Migrant Care which changed its name to the program of Support and Orientation to Migrants in the State. The same thing happened with the Creation of Migrant Clubs and Migrant Care, programs that became the Program of Hidalgo Communities Abroad.

On the opposite side we have the Linkage Mechanisms initiative that, because of a lack of budget, stopped making television programs and it was reduced to a Radio program for Migrants. On the other hand, the initiatives of the Small and Medium Investment program were integrated into the operational rules of the $3 \times 1$ for Migrants and Peso x Peso, Dólar x Dólar programs.

At the beginning of this administration, the programs of Approaching United States Authorities and Migration Issues were created. The first one was intended to create ties with American authorities located in Mexico and the second one tried to diminish risks for migrants, exploring their options to obtain a work visa. Also, due to the number of requests received between 1999 and 2005 (since 430 people from Hidalgo lost their lives abroad) the support of the removal of remains was expanded, which became an operational program.

In summary, at the beginning of the administration of Miguel Angel Osorio, the State Plan of Attention to Migrants 2005-2011 defined the basis for the operation of the 14 programs dedicated to migratory care.

However, from 2005 to 2009 , several factors such as political and economic changes as well as the new demands of migration dynamics in Hidalgo coupled with the adjustments in the budget of the state government, caused their modification and, in some cases, some established programs were eliminated. Consequently, the Peso x Peso, Dólar x Dólar initiative was discarded, taking its proposals to the $3 \mathrm{x} 1$ for Migrants program. Also, the Migrant Invest in Mexico (Hidalgo) program ended in 2007 having obtained modest results. Also, due to the lack of sufficient financial results, the Radio Program for migrants was cancelled. Finally, adjustments in migration care policy led to the implementation of new programs that sought to integrate all migratory care programs into one single mechanism.

\section{Unique Registry of People from Hidalgo Living Abroad (REHUNE)}

In March 2008, the government of the state of Hidalgo proposed a comprehensive migratory care initiative considered as an unprecedented public policy effort in the country. In the opinion of the then Director of the CAHIDEE: "The government of Osorio Chong seeks to implement a new tool of social support for those who have left, this tool is called REUNHE [...], it is a unique national program in its entirety. There is nothing like it, although there are states that have implemented something similar, none of them has this program".

The originality mentioned by the official was based on the operation of the program which in general terms included two aspects: it incorporated 
all the lines of action of the State Support Program for Migrants 2005-2011 (SEDESO 2010) and it combined many of the operative programs to create a type of comprehensive migratory care system.

The operation of REUNHE considered creating a migrant registry based on information from North America and the municipalities of Hidalgo. Basing on this registry, the program mechanism comprised three actions. The first one was to provide migrants and their families in the state with identification documents such as birth certificates, CURP, among others, and it also offered legal advice. The second action was aimed at providing a monetary system for both the management of their income in the United States as well as for sending and receiving remittances. Finally, the third action was the structuring of productive projects with the goal of creating small businesses in the high migratory intensity municipalities in the state. During its first year of operation, REUNHE registered around 45 thousand migrants from Hidalgo among whom more than 18 thousand cards were delivered in order to send remittances. In addition, 10 million pesos were given for the establishment of 112 productive projects. This generated 289 jobs in 28 municipalities, directly benefiting 1.291 people from Hidalgo.

However, despite the good intentions of the government to promote comprehensive migration care, the program had errors due to a lack of transparency in key aspects such as real costs, the financing of productive projects and the information security of the migrants' registry. This happened because there was no public bidding contest so the Global Search company could provide this service in the United States. The amount of discount cards given by the government of the state of Hidalgo was known, but the profit obtained by the private company was not disclosed. The foreign company that provided the service in the United States was susceptible of being intervened for security purposes, since illegal migration is punished by the USA Patriotic Act. Also, resources from the 3x1 Program for migrants were intended to be used in a discretionary manner, only with the participation of the state government and the migrants, which violated the rules of operation that require the participation of three government levels and its approval through the Committee of Work validation. In this context, the REUNHE program was only operating for a year and a few months, because after the exit of the promoter of this initiative, the Secretary of Social Development (SEDESO) David Pechina Grub, the program reduced its activities. In this sense, it is not unreasonable to assert that the official used the program as a part of a political strategy that would help him achieve a candidacy of the PRI for a Federal Government position -which he finally achieved- and not as a platform to provide real support to Hidalgo's migrants. Upon the arrival of a new head of the SEDESO, the activities of the REUNHE program were diminishing until it disappeared completely.

By the end of 2012, the change to the administration of Francisco Olvera Ruiz continued the work of CAHIDEE, giving it the category of General Directorate of Attention to Migrants (DGAM) and until 2015 it is said to be operating 14 programs. The migrant community also approved the programs,
The role of the state of Hidalgo in the public policies for the Hidalgo inhabitants abroad

Edgar Manuel Castillo Flores Berenice Alfaro Ponce 
Dossier América Latina: fronteras y zonas fronterizas as not only did their basic demands continue to be met, but also the coverage of many programs was extended. (See Appendix 1). But above all, there was a great advance in the program of creating migrant organizations.

\section{DGAM operational programs}

According to the Operating Rules of the Social Development Programs of the State of Hidalgo (SEDESO 2010) and the government reports of the administration of Francisco Olvera Ruiz (2012-2015), until 2015 there were at least 14 programs for migrants (See Appendix 1.). However, some of these initiatives only existed on paper, since no relevant activity has been reported in recent years. Going further with this information, we will briefly describe each one of the cases.

\section{Bienvenido Hidalguense}

The Bienvenido Hidalguense program was one of the first alternatives of the state government to support its migrant communities and it was originated because the Bienvenido Paisano program did not cover all needs. As a result, migrants started to seek their own means of protection and support. During the 1990s, the Supreme Hñahhu Council implemented the Informed Indigenous Migrant, in order to protect migrants from the Valle del Mezquital. Based on this non-governmental initiative and juxtaposed to the gradual increase of complaints from Hidalgo migrants, in 1999, the Hidalgo government decided to expand and improve the attention of the federal program, creating the Bienvenido Hidalguense initiative.

During its first year of operation, the program was recognized for its results by the Government Secretariat, the CONOFAM and other non-governmental organizations (Vargas 2007). Subsequently, in 2003, an orientation and support module from the state government was established at the border between Sonora and Arizona. And in 2005, in Hidalgo's area, 20 permanent modules of support, assistance and permanent patrol were established, as well as 4 security corridors that support the return of Hidalgo migrants. Similarly, Hidalgo migrant organizations like the Hidalgo Federation in Nevada, have created their own defense mechanisms such as caravans they organize at the end of the year to return to the state.

\section{Support and Orientation for Migrants in the State and Abroad}

Established in 2005, this initiative seeks to formulate assistance policies that benefit Hidalgo's migrants and determine priorities for the development of attention programs. Its objective is to give specialized guidance to Hidalgo's 
migrants settled in the United States through interaction and coordination strategies of all people involved in the migration phenomenon in Hidalgo (SEDESO 2010). Until 2006, the results of this program report a series of interinstitutional meetings between authorities of the three government orders in Mexico and the United States. However, since 2007, no activity has been registered.

Hidalgo Communities Abroad

Having as background the Creation of Migrant Clubs and Attention to Migrants, in 2005, this initiative is consolidated in order to seek permanent contact with Hidalgo's migrants in the United States. The objectives of this program are the creation and strengthening of organizations, clubs and federations of migrants from the state as well as supporting civic or festive events of the Hidalgo community in the United States (SEDESO 2010). Within the frames of this program, the Hidalgo House for the people from Hidalgo who live in the United States of America was inaugurated on September 24, 2012. Thanks to this initiative, the government of the state of Hidalgo has managed to create communication channels to link directly with the migrants from Hidalgo in the United States.

\section{Investigation and Analysis}

This program was created in 2005, based on the Observatory of International Migration from Hidalgo, seeking support of specialized institutions in the study of migration between Mexico and United States. The purpose was to generate studies and investigations on the origin, transit and destination of migrants from Hidalgo, their migration profile and work activities and the impact this phenomenon has on the state (SEDESO 2010). Among the results of this initiative is the Diagnosis of the state of Hidalgo around the migratory phenomenon (INEGI and CAHIDEE 2004), a study on the Organizational dimension of Hidalgo migrants in the United States (Escala 2006) and the relationship between international migration and poverty in the state of Hidalgo (Serrano 2006). Subsequently, between 2007 and 2010, it is mentioned that there are ten pending research projects without any being published. However, the government reports from 2011 to 2015 mention a pilot study in 26 communities of municipalities with high migratory intensity in the state, which culminated with the publication of the book People from Hidalgo in the US: the Dream after the Journey (DGAM 2016) and the project called "Barometer of the Hidalgo Migrant in Houston, Texas and Conurbated Areas", whose objective is to make known the living conditions of the people from Hidalgo in that part of the United States.
The role of the state of Hidalgo in the public policies for the Hidalgo inhabitants abroad

Edgar Manuel Castillo Flores Berenice Alfaro Ponce 


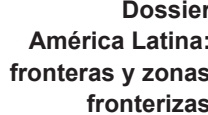

América Latina:

fronterizas

\section{Let's Talk Migration}

The program was established in the year 2000 with the aim of setting up mechanisms that would permit the municipalization of the migration policy through cooperation agreements with 84 municipalities for the creation of migration assistance offices in the municipalities (SEDESO 2010). In its development, a series of informative meetings and workshops were held in educational institutions and with the population, mainly in communities with high migration in the state (Vargas 2007). Among the results obtained, in 2006 the first municipal office to serve migrants was inaugurated in Tenango de Doria.

\section{I am Already Hidalguense}

Created in 2001, the program advocates to provide documentation that certifies the Mexican nationality of the sons of people from the state of Hidalgo, who were born outside the national territory of Mexico. The program facilitates the procedure of double nationality to the migrants from Hidalgo and allows them to enjoy all their rights as any Mexican citizens. Furthermore, it includes the guidance and support to transact birth certificates, the translation of official documents and the issuance of a Unique Population Registry Code in Mexico - CURP (SEDESO 2005). The results mention that in 2001 and 2015, 7.397 birth certificates were delivered along with the same number of UPRC (CURP). More than 5 thousand actions of advisory, apostil, translation of documents, certification procedures among others. ${ }^{3}$ Owing to these results, this program is another case of success received with major acceptance among the migrant community of Hidalgo migrants in the United States.

\section{Approach between Mexican Authorities and Foreign Authorities}

Created in 2005, the program seeks to warrant a major approach between the migrant community of Hidalgo with the governmental authorities of the Mexican government (federal, state, and municipal) and its counterpart in the US settled in national territory (embassy, general consulate, etc.). The purpose of this linkage is to strengthen a culture of conjoint work and cooperation among countries (SEDESO 2005). Nevertheless, since its creation it does not register any result or improvement and it is only mentioned within the Cooperation Rules of Programs of Social Development (SEDESO 2010).

\footnotetext{
3 Author's calculations based on the findings of governmental reports of Manuel Ángel Núñez (1999-2005) and Miguel Ángel Osorio (2005-2011) administrations and five reports of the government of Francisco Olvera Ruiz (2011-2015).
} 
International Linkage

The program is created in 2005 with the purpose of attending and follow the investment projects that migrants from Hidalgo propose (SEDESO 2010). Within the frames of this program the government seeks to intervene in the mechanisms of management of social investment. However, the operation lines are not clear. In conjoint work with the program Approach with Mexican Authorities and Foreign Authorities, this enterprise seems to lack impact and follow-up as, since its creation until 2015 , no results were reported. ${ }^{4}$

\section{Corrective Protection and Juridical Identity}

The actions of corrective protection are the main activities offered by the state offices in attention to migrants (OFAMs) in Mexico. In Hidalgo, this program has the objective to attend the requests for support presented by migrants and their relatives in the state (SEDESO 2005). Between lines of action of this program, the support for the location of missing Hidalgo citizens is included; repatriation of sick; support in case of custom matters; legal assessment to Hidalgo citizens retained for migratory and other crimes; humanitarian visas; international alimony; economical compensation due to migrant's death, repatriation of underage citizens; return to the community of origin; tourist visas and group visas; specialized assessment.

\section{Migratory Matters}

With the aim of providing adequate information about the diverse migratory formalities in the consulate of the United States (obtainment of job visas or migratory regularizations), the program Migratory Matters was created in 2005. Its objective is to prevent risks for migrants who intend to cross the border illegally by exploring their possibilities for obtaining a work visa (H2A/ $\mathrm{H} 2 \mathrm{~B}$ ), to avoid the individual and familiar imbalance due to consequences of deportation and to evaluate the possibilities of migratory regularization for illegal Hidalgo citizens in the United States (SEDESO 2005). The results of this program have been modest, since the government points out that, between 2006 and 2015, this initiative provided assessment to possible candidates for obtaining a temporary job in the United States, from which only 31 petitions received the $\mathrm{H} 2 \mathrm{~A} / \mathrm{H} 2 \mathrm{~B}$ visas. ${ }^{5}$

4 Data presented in the 2nd, 3rd and 4th government report of Miguel Ángel Osorio Chong and the 5 reports of Francisco Olvera Ruiz (2011-2015).

5 Data presented in the 2nd, 3rd and 4th government report of Miguel Ángel Osorio Chong and the 5 reports of Francisco Olvera Ruiz (2011-2015).
The role of the state of Hidalgo in the public policies for the Hidalgo inhabitants abroad

Edgar Manuel Castillo Flores Berenice Alfaro Ponce 


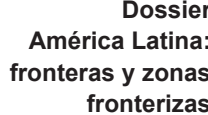

América Latina:

fronterizas

\section{Transfer of Remains}

The Transfer of Remains is a request of support recurrent to the state authorities by the relatives of a diseased migrant abroad. Since 1999, this support comprises of one of the firsts actions of Corrective Protection that are developed. It is a paramount that in 2005, due to the rise in the number of petitions, this activity acquires the level of operational program (SEDESO 2005). Furthermore, in case of the transfer to the community of origin of Hidalgo citizens that die abroad or in an attempt to cross the border illegally, it is expected that funeral agencies in the US apply low fares. Between 1999 and 2015, this program has attended the petitions for transfer of remains of 1167 Hidalgo citizens. $^{6}$

\section{Mechanisms for the support of migrants}

The program starts in 2008. Its objective is to provide tools that help migrants to have access to better services in the US and in Mexico. Among the benefits that are provided to the migrants from Hidalgo is a card with discounts on medicines with validity in pharmacies in the US and issuing of Hidalgo driving licenses in the US (SSP 2008). The discount cards are delivered through the municipal network of linkage or through the families of migrants, but the number of beneficiaries, the coverage or the total of savings that the community of migrants from Hidalgo received is unknown. The issuance of licenses, on the other hand, is managed by a company of the United States and the General Direction of Public Security and Transit of the State of Hidalgo (DGEPTEH). Notwithstanding, this document has serious limitations. In both programs there has not been any follow-up reported, therefore it can be considered as canceled.

\section{Support Fund to Migrants}

Implemented in 2009, this program has two objectives. Firstly, improving the expectations of the population and achieve a human development through the support of productive projects, whether they are individual or in group. Secondly, the improvement of living conditions through the acquisition of materials for hardboard flooring, reinforcement of ceilings and walls, latrines, septic tanks, etc. The beneficiaries are the migrants that return temporarily or definitively to Mexico and their families that receive remittances. Among 563 municipalities selected in the country were Hidalgo, La Misión, Pacula, Acatlán, Alfajayucan, Cardonal,

6 Own calculations based on the reports of the Manuel Ángel Núñez (1999-2005), Miguel Osorio (2005-2011) and Francisco Olvera (2011-2015) administrations. 
Chicuautla, Eloxochitlán, Jacala, Tenango and Tizayuca. ${ }^{7}$ In order to get financing, the chamber of deputies authorized a total sum of 300 million Mexican pesos, from which the state of Hidalgo would receive 3.968.919; in other words, $1,3 \%$ of the total sum of the program, using such budget between 2009 and 2011. ${ }^{8}$ To 2010, the government of Hidalgo delivered resources for the amount of 1.272.500 pesos, which provided funding to start 101 projects of productive investment. In 2011, there were invested 1.542 .521 pesos. ${ }^{9}$ Eventually, this program was terminated, a program that had an investment of more than 5 million Mexican pesos and registered a total of 788 projects in the state of Hidalgo. Despite of being a good initiative and with a great level of acceptance and participation of many migrants from Hidalgo, the operation was quite ambiguous.

\section{Initiative $3 \times 1$ for Migrants}

The program 3x1 for Migrants is an activity which responds to the initiatives of the organizations or federations of migrants along with the participation of three levels of government in Mexico. Overall, its goal is to carry out infrastructure works, productive projects and community development in the places of origin of migrants. In case of the state of Hidalgo, this initiative of community development started to work since 2002 (SEDESO 2005, SEDESO 2010).

\section{Final notes}

During the last decade, the government of the state of Hidalgo has made a considerable effort in the attention to migrant's welfare. While even before 1990, even with a Federal Initiative existing which was focused on migrants, in Hidalgo there was no concrete policy and the local authorities were still dismissing migration matters.

From 1999, the state government gave a full spin to its attitude towards migrants, both in its political agenda and in the normative sense, proposing diverse plans and state programs. This was widely reflected in the establishment of CAHIDEE and its attention programs, which afterwards would become the General Directive of the Assistance to Migrants. This institution has been set up as an initiative that is convenient not only for the state government, but also for the migrants from the state of Hidalgo. Of course, due to the nature of the topic, it ends up being rather difficult to objectively evaluate the operation and the

\footnotetext{
7 Interview with the secretary of Social Development of Hidalgo, 8th of April 2009.

8 Information from the Secretariat of Finance and Public Credit (SHCP) seen in: http:// www.shcp.gob.mx/EGRESOS/PEF/TEMAS_GASTO_FED/Paginas/fondo_apoyo_migrantes. aspx, consulted on 20 September 2010.

9 Information from the 5th and 6th Government Report of Miguel Ángel Osorio Chong.
}

The role of the state of Hidalgo in the public policies for the Hidalgo inhabitants abroad

Edgar Manuel Castillo Flores Berenice Alfaro Ponce 
Dossier América Latina: fronteras y zonas fronterizas outcomes of this public policy. It is necessary to state that the clarification and explanation of this chapter gave way to know that the migration phenomenon has been developed in the political agenda and the corresponding response developed by the Hidalgo authorities regarding this phenomenon.

Nevertheless, there are plenty of indicators of the progress of the state migratory policy, such as the quantitative growth of the organizations of migrants in Hidalgo or the design, formulation and improvement of new initiatives with regards to migratory assistance in an attempt to create a comprehensive system of assistance. In other words, a transnational policy of migration that would benefit migrants from Hidalgo in the United States and their families in the home state in a single place. However, this progress differs with previous research about migratory policies in Hidalgo. This research points out, on the one hand, the incongruity in the state government's discourse regarding the importance of the migration phenomenon and, on the other hand, the lack of information for migrants and their distrust in the performance of the state government (Vargas 2007). Moreover, attention is drawn to the fact that the migrants from Hidalgo are an absent actor in these programs (Frias et al. 2007).

Of course, as in every state of the country, there are plenty of deficits and limitations in migratory assistance. In case of Hidalgo, a limited capacity of conducting a more complete intervention is largely owed to its management and also due to the lack of economic resources. Because even the budgets from a federal level or a state level take time to reach this institution, which, invariably, affects the continuity of the programs.

It is important to mention that another factor that has limited the development of the migratory assistance in this state is a double political interest regarding this kind of activity. Two cases can serve as an example. The first one is the case of the ex-governor Manuel Ángel Núñez Soto who tried to become the PRI candidate in the presidential elections in 2006. His administration promoted a visible approach to the migrant organizations, founded the CAHIDDE and created several assistance programs that were driven by his own political interest ( Frias et al. 2007).

The second case regards an attempt to establish a system of integral migratory assistance (REUNHE), since the main goal of the ex-secretary of Social Development (SEDESO), David Penchina, was to use this initiative as part of his political strategy in order to reach a candidacy for federal deputy. There can be added one more recent case of the ex-director Erika Saab, who abandoned her position in order to become a candidate for federal deputy. The mentioned cases indicate that sometimes activities aimed at supporting migrants from Hidalgo, instead of helping them, are used as a political platform for projects of personal interests.

In any case, although the programs carried out by DGAM involve an important number of migrants and their families, a large number of migrant communities abroad are unaware of the Hidalgo authorities' attempts to address problems and challenges triggered by the migratory phenomenon. 
Therefore, a broader dissemination within the state is necessary, so that families and the migrants themselves have knowledge of where to go to solve their doubts or problems related to migration.

However, in order to carry out actions that improve the effectiveness of the DGAM's performance, it is essential that the state government recognize in greater detail the importance and the dimension of the Hidalgo's migration to the United States. Furthermore, it is of utmost importance to carry out an analysis of the costs and benefits of comprehensive assistance to migrants, regardless of the mere political benefits that this may represent and to allocate more funding to programs and projects of the DGAM, considering them as a kind of investment in the economic and social capital that migrants can contribute to the state because the more efficient the migratory attention, the greater the benefits of the migratory phenomenon in the social structure of the families from Hidalgo.

From now on, it is worth to carry out analysis regarding the following questions: the impact of migration in the local development of the state; the role of the remittance from Hidalgo migrants in diminishing poverty in the state; the role of migrants in the field which should be, in principle, the government's obligation.

\section{Government Report}

Programas Atención migratoria en el Estado de Hidalgo 1999-2015

\begin{tabular}{|c|c|c|}
\hline 1999-2004 & 2005-2009 & 2015 \\
\hline 1 Bienvenido Hidalguense & 1 Bienvenido Hidalguense & 1 Bienvenido Hidalguense \\
\hline 2 Creación Club de Migrantes & 2 Comunidades Hidalguense en el Exterior & 2 Comunidades Hidalguense en el Exterior \\
\hline 3 Atención a Migrantes & $\begin{array}{l}3 \text { Apoyo y Orientación a los Migrantes en el } \\
\text { Estado }\end{array}$ & $\begin{array}{l}3 \text { Apoyo y Orientación a los Migrantes en el } \\
\text { Estado }\end{array}$ \\
\hline 4 Hablemos de Migración & 4 Hablemos de Migración & 4 Hablemos de Migración \\
\hline 5 Ya Soy Hidalguense & 5 Ya Soy Hidalguense & 5 Ya Soy Hidalguense \\
\hline 6 Observatorio Permanente de Migr & 6 Investigación y Análisis & 6 Investigación y Análisis \\
\hline 7 Mecanismos de Vinculación & 7 Acercamiento con autoridades de & 7 Acercamiento con autoridades de \\
\hline 8 Migrante Invierte en México & Estados Unidos en México & Estados Unidos en México \\
\hline 9 Peso x Peso. Dólar x Dólar & 8 Asuntos Migratorios & 8 Asuntos Migratorios \\
\hline 10 Pequeña y Mediana Inversión & 9 Peso x Peso. Dólar x Dólar & 9 Enlace Internacional \\
\hline 11 Protección correctiva & 10 Programa Radiofónico para Migrantes & 10 Mecanismos de Apoyo a los Migrantes. \\
\hline Gestión de Programas Federales & 11 Traslado de Restos & 11 Traslado de Restos \\
\hline $\begin{array}{l}12 \text { 3X1 Para Migrantes } \\
\text { Apoyo Institucional }\end{array}$ & $\begin{array}{l}12 \text { Protección correctiva } \\
\text { Gestión de Programas Federales }\end{array}$ & $\begin{array}{l}12 \text { Protección Correctiva } \\
\text { Gestión de Programas Federales }\end{array}$ \\
\hline Programa Binacional Educación & 13 3X1 Para Migrantes & $133 \mathrm{X} 1$ Para Migrantes \\
\hline Vete Sano, Regresa Sano. & $\begin{array}{l}14 \text { Migrante Invierte en México (Hidalgo) } \\
\text { * Ristema Integral } \\
\text { * Reunhe Apoyo Institucional } \\
\text { Programa Binacional Educación } \\
\text { Vete Sano, Regresa Sano. }\end{array}$ & $\begin{array}{l}14 \text { Fondo de Apoyo a Migrantes } \\
\text { Apoyo Institucional } \\
\text { Programa Binacional Educación } \\
\text { Vete Sano, Regresa Sano. }\end{array}$ \\
\hline
\end{tabular}

Source: prepared by the authors, based on Vargas (2007), Escala (2006), SEDESO $(2005,2010)$, CAHIDEE $(2005,2007)$ and data from the reports of Manuel Ángel Núñez (1999-2005), Miguel Ángel Osorio (2005-2011) and Francisco Olvera (2011-2015).
The role of the state of Hidalgo in the public policies for the Hidalgo inhabitants abroad

Edgar Manuel Castillo Flores Berenice Alfaro Ponce

\section{Annex 1.}

Programs for migrant assistance in the state of Hidalgo 1999-2015 


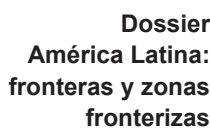

\section{Bibliographic references}

Anduiza E., Crespo I., Mendez M. (1999), Metodología de la Ciencia Política, CIS, Madrid.

Bartolini S. (1999), Metodología de la Investigación Política, en: Manual de Ciencia Política, G. Pasquino (ed.), Alianza Universidad, Madrid.

Blanco C. (2007), Transnacionalismo. Emergencia y fundamentos de una nueva perspectiva migratoria, "Revista de Sociología", no 85, pp. 13-29.

CAHIDEE (2005), Presentación General: Coordinación de Apoyo al Hidalguense en el Estados y el Extranjero, Gobierno del Estado de Hidalgo, Pachuca.

CAHIDEE (2007), Presentación General: Coordinación de Apoyo al Hidalguense en el Estados y el Extranjero, Gobierno del Estado de Hidalgo, Pachuca.

CONAPO (2012), Índices de Intensidad Migratoria México-Estados Unidos, 2000, Consejo, Nacional de Población, México.

DGAM (2014), Hidalguenses en EU: el sueño después de la travesía, Dirección General de Atención al Migrante, Gobierno del Estado de Hidalgo.

Diario Oficial de la Federación (D.O.F.), 8 de Abril de 2009. (DECRETO que crea la operación del Fondo de Apoyo a Migrantes).

Diario Oficial de la Federación (D.O.F.), 29 de enero de 2010 (DECRETO que crea las Reglas de operación del Programa 3x1).

Escala Rabadán L. (2006), Dimensión organizativa de la migración hidalguense en Estados Unidos, Gobierno del Estado de Hidalgo.

Frías N., Ibarra M., Rivera L. (2007), La organización comunitaria. Actor ausente en la reglamentación del Programa 3x1 para Migrantes en Hidalgo, en: El Programa 3x1 para Migrantes ¿Primera Política Transnacional en México?, R. Fernández de Castro et al. (coords.), M.Á. Porrúa, UAZ, ITAM, México.

García y Grieco M., Verea M. (1988), México y Estados Unidos frente a los indocumentados, UNAM/Porrúa, México.

Glick Schiller N., Basch L., Blanc Szanton C. (1992), Towards a Transnational Perspective on Migration: Race, Class, Ethnicity and Nationalism Reconsidered, The New York Academy of Sciences, New York.

Gobierno del Estado de Hidalgo (2005), Carta Geográfica del Estado 2005-2011, Gobierno del Estado de Hidalgo.

Gobierno del Estado de Hidalgo (2005), Plan Estatal de Desarrollo PED 2005-2011, Gobierno del Estado de Hidalgo.

Gobierno del Estado de Hidalgo (2007) Actualización del Plan Estatal de Desarrollo PED 2007-2011, Gobierno del Estado de Hidalgo.

Gobierno del Estado de Hidalgo (2011), Plan Estatal de Desarrollo PED 2011-2016, Gobierno del Estado de Hidalgo.

Goldring L. (1999), El Estado mexicano y las organizaciones trasnmigrantes: Reconfigurando la nación y las relaciones entre el Estado y sociedad civil, en: Fronteras fragmentadas, G. Mummert (coord.), Colegio de Michoacán, México.

Goldring L. (2002), The Mexican State and Transmigrant Organizations: Negotiating the Boundaries of Membership and Participation, "Latin American Research Review", vol. 37, no 3, pp. 55-99. 
INEGI y CAHIDEE (2004), La Migración en Hidalgo, Instituto Nacional de Geografía e Informática, Coordinación de Apoyo al Hidalguense en el Estado y el Extranjero, Hidalgo.

Itzigsohn J. (2000), Immigration and the Boundaries of Citizenship: The institutions of immigrants' political transnationalism, "International Migration Review", vol. 34, no 4, pp. $1126-1154$.

Moctezuma M. (2003), La experiencia de las remesas comunitarias del club de migrantes El Remolino, Zacatecas, en: Enfrentando la globalización Respuestas sociales a la integración económica de México, L Carlsen, T. Wise, H. Salazar, M.Á. Porrúa, México.

Periódico Oficial del Estado de Hidalgo, Gobierno del Estado de Hidalgo, viernes 29 de diciembre de 2006. (DECRETO Ley de Desarrollo Social del Estado de Hidalgo).

Periódico Oficial de Hidalgo, Gobierno de Hidalgo, 13 de junio de 1994. Última reforma del 28 de marzo de 2011, consultada el 1 de abril de 2013. (DECRETO Ley Orgánica de la Administración Pública para el Estado de Hidalgo).

Portes A., De wind J. (2006), Repensando las migraciones. Nuevas perspectivas teóricas y empíricas, M.A. Porrúa, México.

Portes A., Guarnizo L., Landlot P. (1999), The Study of Transnationalism: Pitfalls and Promise of an Emergent Research Field, "Ethnic and Racial Studies", vol. 22, no 2, pp. 217-237.

Schmidt E., Crummett M. (2004), Herencias recreadas: capital social y cultural entre los hñahñu en Florida e Hidalgo, en: Indígenas mexicanos migrantes en los Estados Unidos, J. Fox, G. Rivera, M.A. Porrúa y UAZ, México.

SEDESO (2005), Plan Estatal de Atención a Migrantes 2005-2011, Secretaría de Desarrollo Social, Hidalgo.

SEDESO (2010), Reglas de operación de los Programas de Desarrollo social en estado de Hidalgo, Secretaría de Desarrollo Social, Hidalgo.

Serrano T. (2006), Y, se fue... Los municipios hidalguenses de muy alta migración internacional, Universidad Autónoma del Estado de Hidalgo.

Smith R. (2006), Mexican New York: Transnational Lives of New Immigrants, University of California Press, Berkeley.

Smith M., Bakker P. (2008), Citizenship across Borders: The Political Transformation of El Migrante, Cornell University Press, London.

Trejo M. (2010), Las asociaciones de migrantes y su papel en la configuración del desarrollo local en el estado de Hidalgo, Tesis Maestría Desarrollo Regional, COLEF.

Valenzuela M. B. (1999), Fideranza: la política pública de las remesas en Jalisco. Diseño, instrumentación y perspectivas, "Carta Económica Regional", no 69, Noviembre-Diciembre pp. 3-12.

Vargas R. (2007), Políticas migratorias en el Estado de Hidalgo, en: Las políticas migratorias en los estados de México. Una Evaluación, R. Fernández de Castro, R. García Zamora,R. Clariond, A. Vila Freyer, M.Á. Porrúa, UAZ, ITAM, México.
The role of the state of Hidalgo in the public policies for the Hidalgo inhabitants abroad

Edgar Manuel Castillo Flores Berenice Alfaro Ponce 